\title{
PENERAPAN PENDEKATAN ILMIAH (SCIENTIFIC APPROACH) DENGAN PROSEDUR UNDO UNTUK MENINGKATKAN HASIL BELAJAR PADA INVERS FUNGSI
}

\author{
Oleh : \\ SUDARMOYO, M.Pd. \\ SMA Negeri 2 Kuningan, Jl. Arujikartawinata 16 Kuningan \\ email: masmoy2ku@yahoo.com
}

\begin{abstract}
One of the basic competencies that must be mastered class XI-IPA is "Resolving issues related to the inverse function". Basic competence is also one of the indicators in the national exam, so students of class XI-IPA should really master. However, based on the experience of researchers for teaching mathematics, indicates that any repetition of inverse functions are still many students who score below KKM. From the discussion in MGMPs indicated that student difficulties in determining the inverse function due to step determines inverse functions too abstract. Therefore do classroom action research in an effort to improve student learning outcomes in class XI-IPA-7 (Acceleration) SMAN 2 Brass Odd semesters of the school year 2014 to 2015 on the basis of competence finding the inverse of a function by applying a Scientific Approach (Scientific Approach) with Undo Procedure. Application of Scientific Approach (Scientific Approach) with the Undo procedure is proven to improve student learning outcomes in class XI-IPA-7 (Acceleration) 2 SMAN 2 Brass half of the school year 2015 to 2016 on the basis of competence finding the inverse of a function. This is supported by: (1) the results of the competency test is very high. The average results of the competency test in cycle 1 was 88.44 increase in cycle 2 to 97.50. (2) the group's work was optimal. The average results of the group work in cycle 1 was 96.67 increase in cycle 2 to 100 (3) the results of students' activity quite well. Activity of students in cycle 1 was 83.95 increase in cycle 2 to 96.30. Based on the conclusion, delivered the following suggestions: (1) The Scientific Approach (Scientific Approach) with the Undo procedure can increase the activity of learning and student learning outcomes in basic competency finding the inverse of a function. And (2) To other researchers suggested that trying to conduct action research class that implements the Application of Scientific Approach (Scientific Approach) for the other subjects.
\end{abstract}

Keywords: Scientific Approach, Procedures Undo, Inverse function.

\section{PENDAHULUAN}

Salah satu kompetensi dasar yang harus dikuasai siswa kelas XIIPA semester Ganjil adalah "Menyelesaikan masalah yang berkaitan dengan fungsi invers". Kompetensi dasar tersebut juga menjadi salah satu indikator dalam ujian nasional. Maka dari itu siswa kelas XI-IPA harus menguasai bagaimana menentukan fungsi invers.

Namun berdasarkan pengalaman peneliti selama mengajar matematika, menunjukkan bahwa setiap ulangan 
tentang invers fungsi masih banyak siswa yang mendapatkan nilai di bawah KKM. Dari hasil diskusi di MGMP menyimpulkan bahwa kesulitan siswa dalam menentukan fungsi invers disebabkan karena langkah menentukan fungsi invers terlalu abstrak. Hal ini diperkuat dengan pendapay Soedjadi (2008: 41) yang mengungkapkan bahwa "sifat matematika yang abstrak merupakan salah satu penyebab sulitnya seorang siswa dalam belajar matematika". Disisi lain pembelajaran matematika dalam kurikulum 2013 menuntut perubahan pola pikir dalam proses pembelajaran, yang diantaranya adalah: (1) dari berpusat pada guru menuju berpusat pada siswa, (2) dari satu arah menuju interaktif, (3) dari individual menuju kooperatif, (4) dari satu sumber menuju multisumber, dan (5) dari satu media menuju multimedia. Perubahan pola pikir tersebut memaknai bahwa pembelajaran bukan berarti siswa diberi tahu, tetapi pembelajaran adalah mendorong siswa untuk aktif mencari tahu.

Berdasarkan uraian di atas, mendorong penulis untuk menerapkan Pendekatan Ilmiah (Scientific Approach) dengan Prosedur Undo sebagai upaya meningkatkan hasil belajar siswa kelas XI-IPA-7 (Akselerasi) semester Genap SMAN 2 Kuningan tahun pelajaran 2015-2016 pada kompetensi dasar tentang menentukan invers suatu fungsi.

\section{RUMUSAN MASALAH}

Berdasarkan latar belakang masalah sebagaimana yang telah dipaparkan di atas, maka rumusan masalah dalam penelitian ini adalah sebagai berikut.

1. Bagaimanakah perencanaan Pendekatan Ilmiah (Scientific Approach) dengan Prosedur Undo dalam meningkatkan hasil belajar siswa kelas XI-IPA-7 (Akselerasi) semester 2 SMAN 2 Kuningan tahun pelajaran 2015-2016 pada kompetensi dasar menentukan invers suatu fungsi?

2. Bagaimanakah pelaksanaan Pendekatan Ilmiah (Scientific Approach) dengan Prosedur Undo dalam meningkatkan hasil belajar siswa kelas XI-IPA-7 (Akselerasi) semester 2 SMAN 2 Kuningan tahun pelajaran 2015-2016 pada kompetensi dasar menentukan invers suatu fungsi?

3. Bagaimanakah peningkatan hasi belajar siswa kelas XI-IPA-7 (Akselerasi) semester 2 SMAN 2 Kuningan tahun pelajaran 20152016 pada kompetensi dasar menentukan invers suatu fungsi, dengan diterapkanya Pendekatan Ilmiah (Scientific Approach) dengan Prosedur Undo?

\section{LANDASAN TEORI}

\section{Pendekatan Ilmiah (Scientific Approach)}

Pendekatan Ilmiah (Scientific Approach) dalam pembelajaran sebagaimana dimaksud meliputi 


$\begin{aligned} & \text { mengamati, menanya, } \begin{array}{r}\text { mencoba, } \\ \text { menyajikan, }\end{array} \\ & \text { mengolah, }\end{aligned} \quad \begin{aligned} & \text { menyimpulkan, dan mencipta } \\ & \text { (Tomera, 1974). }\end{aligned}$

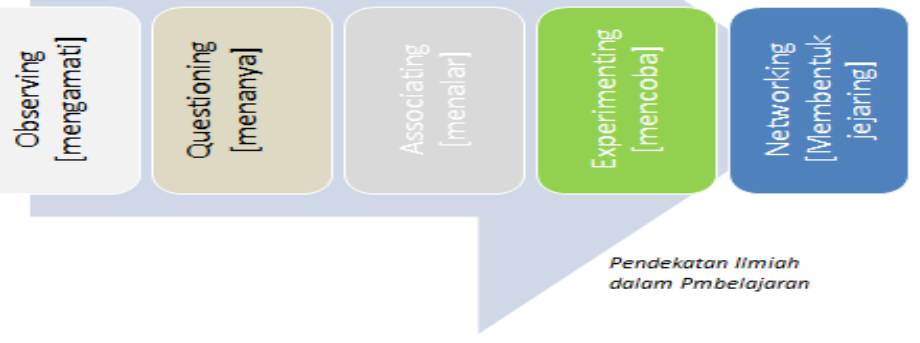

Gambar 1. Langkah Pendekatan

Dalam kenyataannya karakter keilmuan dari matematika berbeda dengan pelajaran yang lain. Maka dari itu penerapan pendekatan ilmiah dalam pembelajarn matematika agak berbeda dengan pelajaran lain. Langkah pendekatan ilmiah dalam

$$
\text { matematik adalah: }
$$

Mengamati, (2) Menannya, Menalar, (4) Mencoba, dan (5) Menyimpulkan.

\section{Pendekatan Ilmiah (Scientific Approach) dengan Prosedur Undo dalam Menentukan Invers Fungsi}

Berikut ini akan diuraikan penerapan Pendekatan Ilmiah (Scientific Approach) dengan prosedur undo dalam menentukan Invers Fungsi

\section{a. Mengamati}

\section{1). Mengamati Fakta}

Mengamati alur perjalanan siswa dari rumah ke sekolah (pergi sekolah) dan alur perjalan dari sekolah ke rumah (pulang sekolah), misal :

Alur Pergi Sekolah : $k e$ selatan, ke timur, ke selatan, ke barat

Alur Pulang Sekolah : $k e$ timur, ke utara, ke barat, ke utara

Jika alur pergi sekolah di misalkan fungsi maka alur pulang sekolah adalah invers fungsinya. Menentukan alur pulang sekolah merupakan anologi berepikir undo dari alur pergi sekolah.

\section{2). Mengamati Konsep}

Dari hasil pengamati fakta dilanjutkan dengan mengamati konsep operasi bilangan dan kebalikannnya.

\section{b. Menanya}

Memberikan pernyataan sebagai upaya membimbing siswa menemukan keterkaitan antara 
fakta diamati dengan konsep menentukan invers fungsi.

c. Menalar

Menalar merupakan proses berpikir yang logis dan sistematis atas fakta yang diamati dan konsep menentukan invers fungsi dengan prosedur undo sebagai berikut.

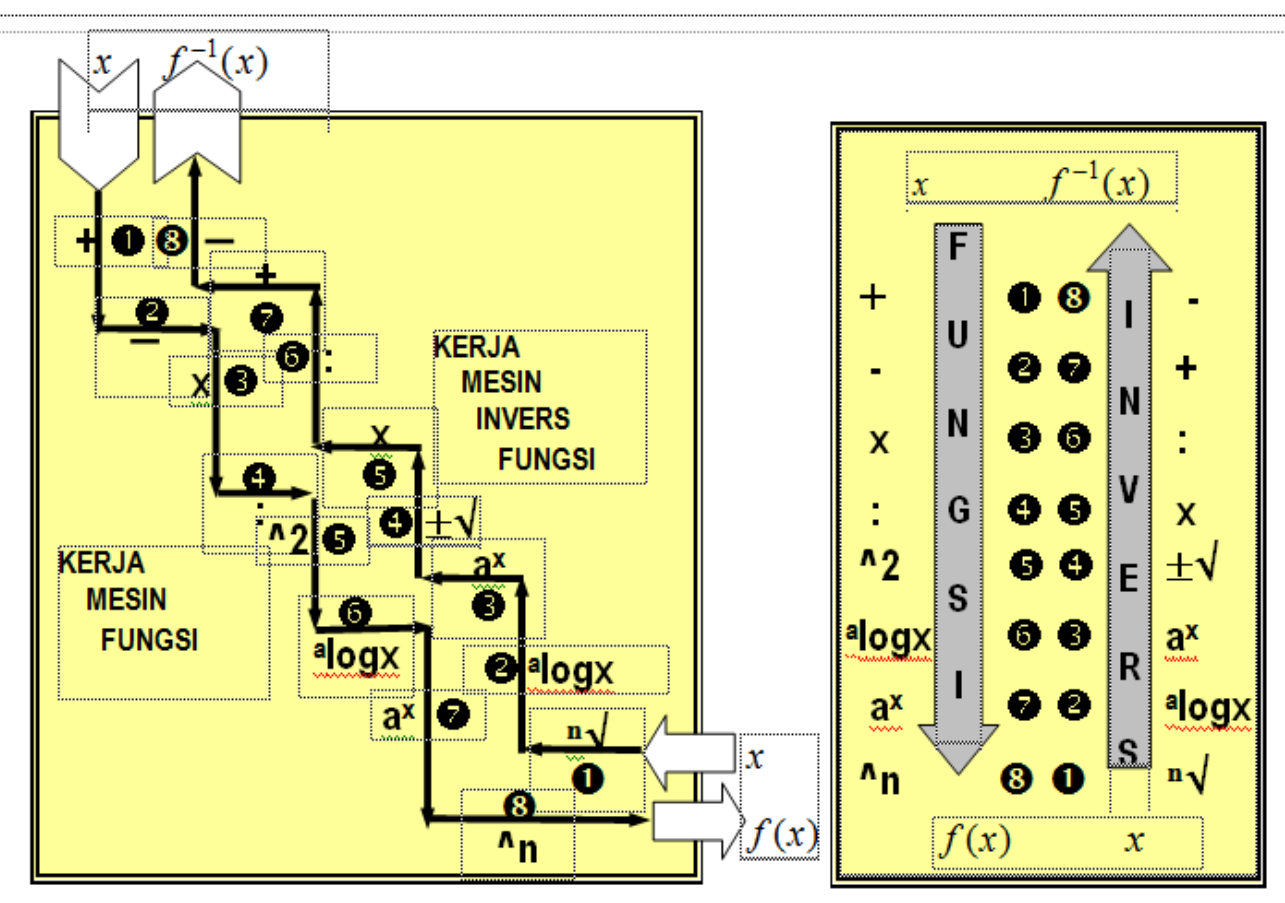

Gambar 2. Konsep Menentukan Invers Fungsi Dengan Prosedur Undo

d. Mencoba dan Menyimpulkan

Berdasarkan hasil menalar tentang keterkaitan konsep menentukan invers fungsi, mencoba menyelesaikan beberapa contoh persoalan. Kemudian dilanjutnya dilakukan proses penyimpulan untuk menemukan rumus umun invers suatu fungsi.

1). Menentukan Invers Fungsi Linier.

a). Mencoba

Tentukan invers dari fungsi linier sebagai berikut!
(1) $f(x)=3 x-6$
(2) $f(x)=4 x+7$

Jawab :

(1) $f(x)=3 x-6$

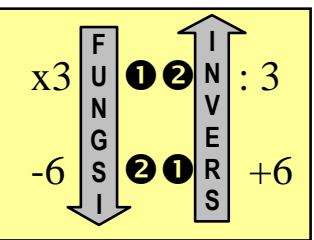

$$
f^{-1}(x)=\frac{x+6}{3}
$$

(2) $f(x)=4 x+7$

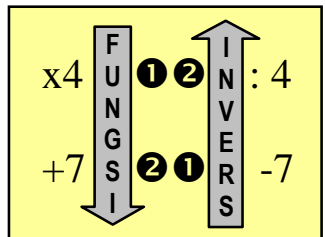

$f^{-1}(x)=\frac{x-7}{4}$ 


\section{b). Menyimpulkan}

Kesimpulan Rumus Umum Invers Fungsi Linier.

Jika : $f(x)=a x+b$

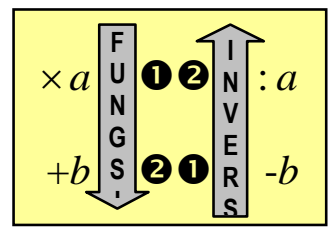

maka $f^{-1}(x)=\frac{x-b}{a}$

2). Menentukan Invers Fungsi Kuadrat.

a). Mencoba

Tentukan invers dari fungsi kuadrat sebagai berikut!

(1) $f(x)=7(x+3)^{2}-5$

(2) $f(x)=x^{2}+2 x-3$

(3) $f(x)=4 x^{2}-16 x+25$

Jawab:

(1) $f(x)=7(x+3)^{2}-5$

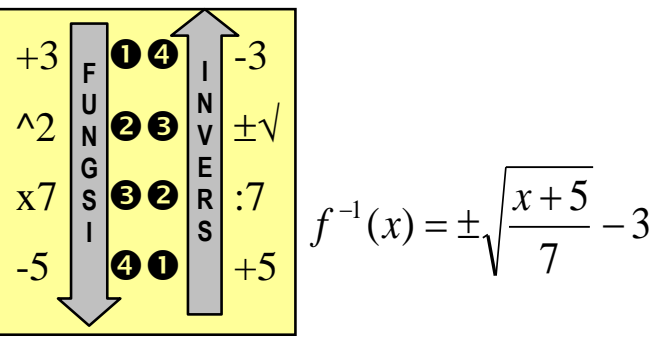

(2) $f(x)=x^{2}+2 x-3$

$f(x)=(x+1)^{2}-4$

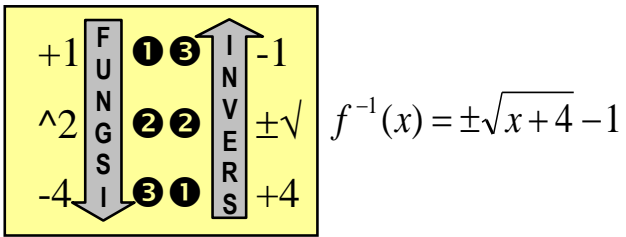

(3) $f(x)=4 x^{2}-16 x-25$

$$
f(x)=4(x-2)^{2}+9
$$

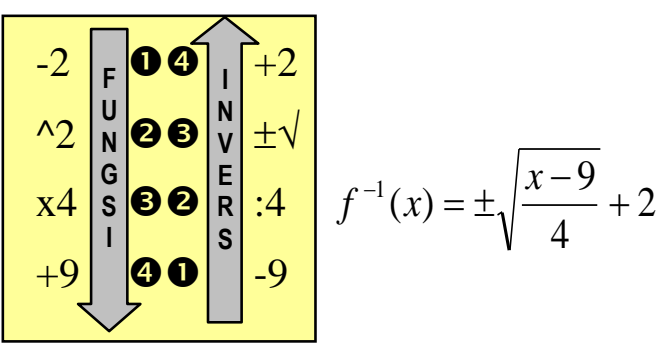

\section{b). Menyimpulkan}

Kesimpulan Rumus Umum Invers Fungsi Kuadrat.

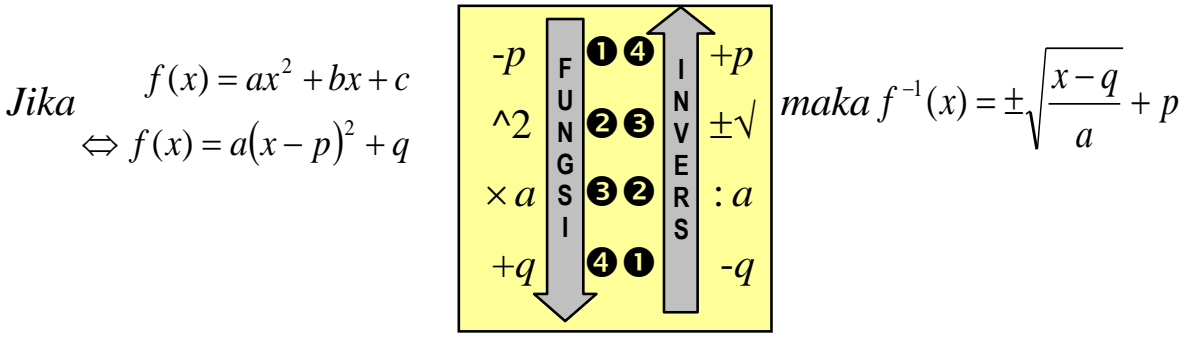




\section{3). Menentukan Invers Fungsi dalam Bentuk Akar}

a). Mencoba

Tentukan invers dari fungsi bentuk akar berikut!

(1) $f(x)=\sqrt[3]{2 x-5}$

(2) $f(x)=\sqrt[5]{\frac{3 x-4}{7}}$

\section{$\underline{\text { Jawab : }}$}

(1) $f(x)=\sqrt[3]{2 x-5}$

(2) $f(x)=\sqrt[5]{\frac{3 x-4}{7}}$

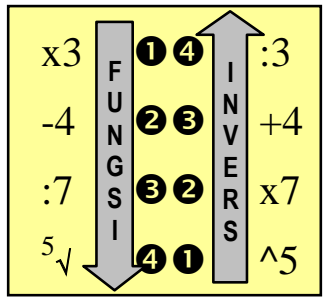

$f^{-1}(x)=\frac{x^{3}+5}{2}$

$f^{-1}(x)=\frac{7 x^{5}+4}{3}$

\section{b). Menyimpulkan}

Kesimpulan Rumus Umuı

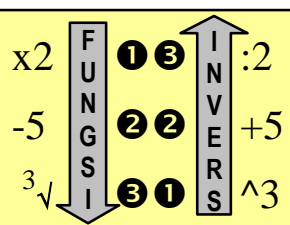

Jika $f(x)=\sqrt[n]{a x+b}$

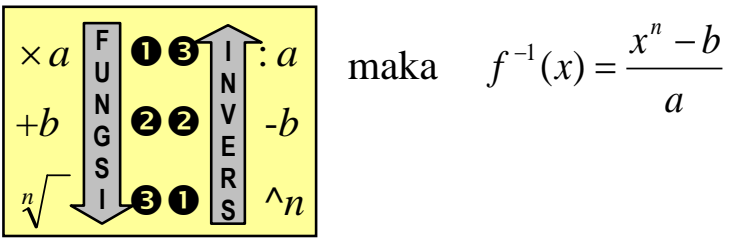

\section{4). Menentukan Invers Fungsi dalam Fungsi Eksponen}

\section{a). Mencoba}

Tentukan invers dari fungsi eksponen sebagai berikut!

(1) $f(x)=5^{2 x-3}$

(2) $f(x)=\frac{2^{3 x}-4}{5}$

$\underline{\text { Jawab : }}$

(1) $f(x)=5^{2 x-3}$

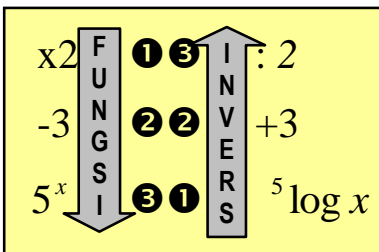
$f^{-1}(x)=\frac{\left({ }^{5} \log x\right)+3}{2}$ 
b). Menyimpulkan

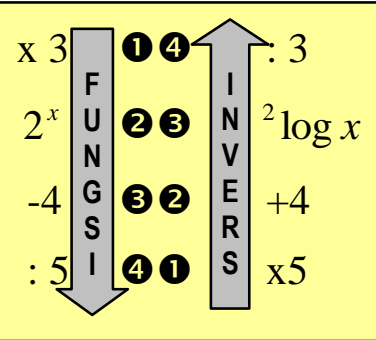

$$
f^{-1}(x)=\frac{{ }^{2} \log (5 x+4)}{3}
$$

Kesimpulan Rumus Umum Invers Fungsi dalam Bentuk Eksponen

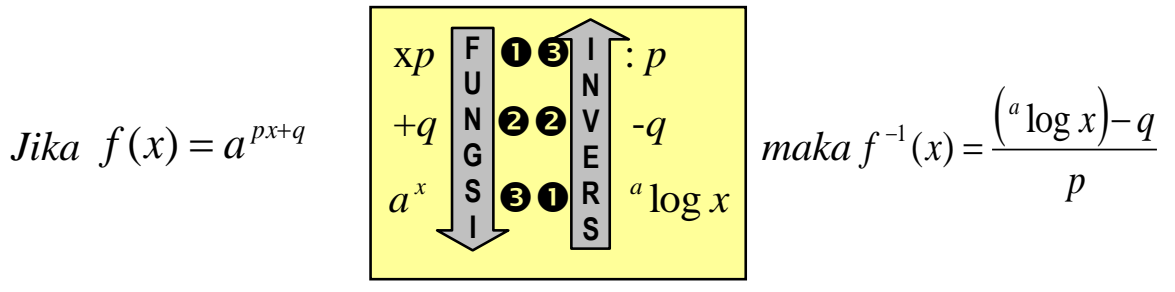

\section{5). Menentukan Invers Fungsi dalam Fungsi Eksponen}

\section{a). Mencoba}

Tentukan invers dari fungsi logaritma sebagai berikut!

(1) $f(x)={ }^{5} \log (2 x+3)$

(2) $f(x)=3 \cdot{ }^{2} \log (5 x-1)+7$

\section{$\underline{\text { Jawab : }}$}

(1) $f(x)={ }^{5} \log (2 x+3)$

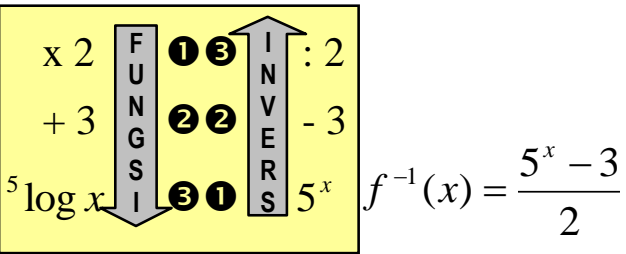

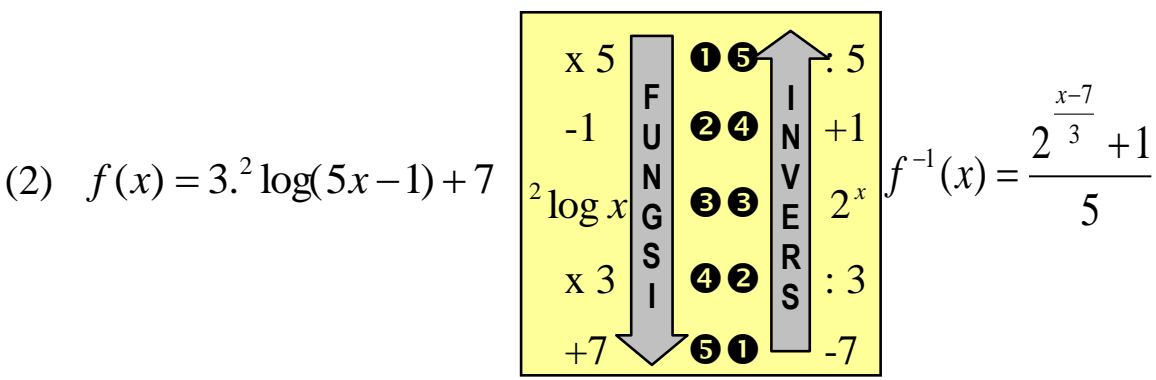

\section{b). Menyimpulkan}

Kesimpulan Rumus Umum Invers Fungsi Logaritma

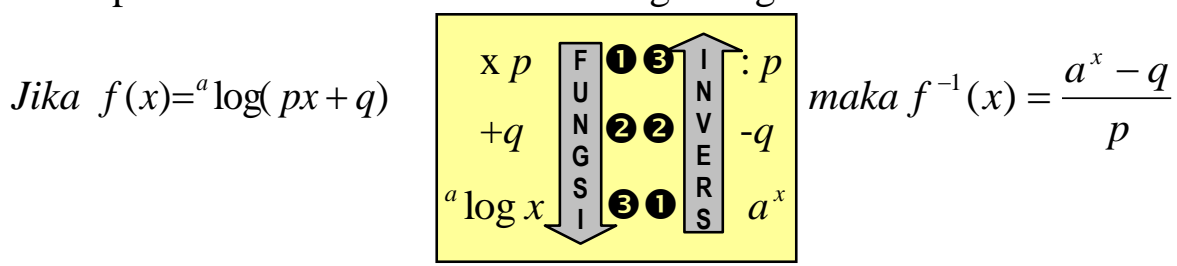




\section{Penerapan pendekatan ilmiah (scientific approach) dengan prosedur undo dalam menentukan invers fungsi di sman 2 kuningan.}

Penerapan Pendekatan Ilmiah (Scientific Approach) dengan Prosedur Undo dalam meningkatkan hasil belajar siswa kelas XI-IPA-7 (Akselerasi) semester 2 SMAN 2 Kuningan tahun pelajaran 2015-2016 pada kompetensi dasar menentukan invers suatu fungsi adalah sebagai berikut

\section{Perencanaan}

Sebelum

penerapan

Pendekatan Ilmiah (Scientific Approach) dengan Prosedur Undo terlebih dulu dilakukan perencanaan sebagai berikut.

a. Melakukan analisis materi tantang menentukan invers fungsi, dalam rangka membuat Rencana Peleksanaan Pembelajaran (RPP). Mengingat materi yang cukup banyak maka pelaksanaan pembelajaran direncanakan dalam 3 pertemuan@2x45 menit.

b. Mempersiapkan materi menentukan invers suatu fungsi dalam bentuk power point.

c. Menyusun Lembar Kerja Siswa (LKS) tentang pada materi menentukan invers fungsi linier dan fungsi kuadrat.

d. Menyusun lembar pengamatan aktivitas belajar siswa.

e. Menyusun tes hasil belajar /uji kopetensi.

\section{Pelaksanaan}

Sebagaimana yang telah direncanakan, bahwa Pelaksanaan pembelajaran Pendekatan Ilmiah (Scientific Approach) dengan Prosedur Undo di kelas XI-IPA-7 (Akselerasi) semester 2 SMAN 2 Kuningan tahun pelajaran 2015-2016 pada kompetensi dasar menentukan invers suatu fungsi dilaksanakan dalam 3 pertemuan @ 2x45 menit. Pertemuan pertama, menekankan bagamana siswa dapat mengamati, menanya, dan menalar prosedur undo dalam menentukan fungsi invers. Pertemuan kedua siswa diarahkan dapat mencoba dan menarik kesimpulan tentang rumus umun Invers Fungsi Linier, Kuadrat, dan Rasional (silkus 1). Pertemuan ketiga siswa diarahkan dapat mencoba dan menarik kesimpulan tentang rumus umun Invers Fungsi Eksponen dan Logaritma (silkus 2). 
Tabel 2.1. Pelaksanaan Pembelajaran

a. Pertemuan 1 (2x45) Menit (Pendahuluan)

\begin{tabular}{|c|c|c|}
\hline NO & FASE & PELAKSANAAN PEMBELAJARAN \\
\hline 1 & $\begin{array}{c}\text { Awal } \\
(10 \text { Menit })\end{array}$ & $\begin{array}{l}\text { Guru memberikan apersepsi, motivasi, dan tujuan } \\
\text { pembelajaran } \\
\text { Guru membagi siswa dalam kelompok kecil yang heterogen }\end{array}$ \\
\hline \multirow[t]{2}{*}{2} & \multirow{2}{*}{$\begin{array}{l}\text { Mengamati } \\
\text { (25 Menit) }\end{array}$} & $\begin{array}{l}\text { Mengamati alur perjalanan siswa dari rumah ke sekolah } \\
\text { (pergi sekolah) dan alur perjalan dari sekolah ke rumah } \\
\text { (pulang sekolah) }\end{array}$ \\
\hline & & $\begin{array}{l}\text { Dari hasil pengamati fakta dilanjutkan dengan mengamati } \\
\text { konsep operasi bilangan dan kebalikannnya }\end{array}$ \\
\hline 3 & $\begin{array}{l}\text { Menannya } \\
(20 \text { Menit })\end{array}$ & $\begin{array}{l}\text { Memberikan pernyataan sebagai upaya membimbing siswa } \\
\text { menemukan keterkaitan antara fakta diamati dengan konsep } \\
\text { menentukan invers fungsi }\end{array}$ \\
\hline 4 & $\begin{array}{l}\text { Menalar } \\
(30 \text { Menit })\end{array}$ & $\begin{array}{l}\text { Siswa melakukan proses berpikir yang logis dan sistematis } \\
\text { atas fakta yang diamati dan konsep menentukan invers fungsi } \\
\text { dengan prosedur undo. }\end{array}$ \\
\hline 5 & $\begin{array}{c}\text { Akhir } \\
\text { (10 Menit) }\end{array}$ & $\begin{array}{l}\text { Menfasilitasi siswa untuk menyimpulkan konsep menentukan } \\
\text { invers fungsi dengan prosedur undo. }\end{array}$ \\
\hline
\end{tabular}

\section{b. Pertemuan 2 (2x45) Menit (Pelaksanaan Siklus 1)}

NO FASE

PELAKSANAAN PEMBELAJARAN

\begin{tabular}{|c|c|c|}
\hline 1 & $\begin{array}{c}\text { Awal } \\
(10 \text { Menit })\end{array}$ & $\begin{array}{l}\text { Guru memberikan apersepsi, motivasi, dan tujuan } \\
\text { pembelajaran } \\
\text { Mengingatkan kembali tentang konsep menentukan invers } \\
\text { fungsi dengan prosedur undo. }\end{array}$ \\
\hline 2 & $\begin{array}{l}\text { Mencoba } \\
(20 \text { Menit })\end{array}$ & $\begin{array}{l}\text { Berdasarkan hasil menalar tentang keterkaitan konsep } \\
\text { menentukan invers fungsi, siswa mencoba menyelesaikan } \\
\text { beberapa contoh persoalan menentukan Invers Fungsi Linier, } \\
\text { Kuadrat, dan Rasional }\end{array}$ \\
\hline 3 & $\begin{array}{l}\text { Meyimpulkan } \\
\text { (20 Menit) }\end{array}$ & $\begin{array}{l}\text { Berdasarkan hasil mencoba, siswa melakukan proses } \\
\text { penyimpulan untuk menemukanarik kesimpulan tentang } \\
\text { rumus umun Invers Invers Fungsi Linier, Kuadrat, dan } \\
\text { Rasional }\end{array}$ \\
\hline \multirow{2}{*}{4} & \multirow{2}{*}{$\begin{array}{c}\text { Akhir } \\
(40 \text { Menit })\end{array}$} & $\begin{array}{l}\text { Siswa Mengerjakan uji kompetensi tentang Invers Fungsi } \\
\text { Invers Fungsi Linier, Kuadrat, dan Rasional }\end{array}$ \\
\hline & & $\begin{array}{l}\text { Guru memberikan penghargaan berupa pujian dan tepuk } \\
\text { tangan serta predikat atas prestasi yang dicapai. }\end{array}$ \\
\hline
\end{tabular}




\section{c. Pertemuan 3 (2x45) Menit (Pelaksanaan Siklus 2)}

\begin{tabular}{|c|c|c|}
\hline NO & FASE & PELAKSANAAN PEMBELAJARAN \\
\hline \multirow{2}{*}{1} & \multirow{2}{*}{$\begin{array}{c}\text { Awal } \\
(10 \text { Menit })\end{array}$} & $\begin{array}{l}\text { Guru memberikan apersepsi, motivasi, dan tujuan } \\
\text { pembelajaran }\end{array}$ \\
\hline & & $\begin{array}{l}\text { Mengingatkan kembali tentang konsep menentukan invers } \\
\text { fungsi dengan prosedur undo. }\end{array}$ \\
\hline 2 & $\begin{array}{l}\text { Mencoba } \\
(20 \text { Menit })\end{array}$ & $\begin{array}{l}\text { Siswa mencoba menyelesaikan beberapa contoh persoalan } \\
\text { menentukan Invers Fungsi Eksponen dan Logaritma secara } \\
\text { berkelompok }\end{array}$ \\
\hline 3 & $\begin{array}{l}\text { Meyimpulkan } \\
\text { (20 Menit) }\end{array}$ & $\begin{array}{l}\text { Berdasarkan hasil mencoba, siswa menlakukan proses } \\
\text { penyimpulan untuk menemukanarik kesimpulan tentang } \\
\text { rumus umun Invers Fungsi Eksponen dan Logaritma }\end{array}$ \\
\hline \multirow{2}{*}{4} & \multirow{2}{*}{$\begin{array}{c}\text { Akhir } \\
(40 \text { Menit })\end{array}$} & $\begin{array}{l}\text { Siswa Mengerjakan uji kompetensi tentang Invers Fungsi } \\
\text { Linier dan Eksponen dan Logaritma }\end{array}$ \\
\hline & & $\begin{array}{l}\text { Guru memberikan penghargaan berupa pujian dan tepuk } \\
\text { tangan serta predikat atas prestasi yang dicapai. }\end{array}$ \\
\hline
\end{tabular}

\section{Paparan Hasil Pembelajaran}

Paparan data hasil penerapan Pendekatan Ilmiah (Scientific Approach) dengan Prosedur Undo di kelas XI-IPA-7 (Akselerasi) semester Genap SMAN 2 Kuningan tahun pelajaran 2015-2016 adalah sebagai berikut.

\section{a. Hasil Pembelajaran Pertemuan Pertama (Pendahuluan)}

Kegiatan dalam pertemuan pertama memuat fase mengamati, mencoba, dan menalar, sehingga evaluasi yang dilakukan hanya observasi terhadap aktivitas siswa

Pada saat pembelajaran siswa telah aktif, hal ini ditunjukkan dengan nilai keaktivan siswa telah mencapai $79,01 \%$ dengan rincian: (1) nilai keaktifan $77,78 \%$; (2) nilai perhatian
$77,78 \%$; dan (3) nilai tanggung jawab $81,48 \%$. Dari 9 siswa terdapat 4 $(44,44 \%)$ siswa memiliki aktivitas dengan kategori B (baik), 5 (55,56\%) siswa memiliki aktivitas dengan kategori C (cukup), dan tak seorangpun siswa yang memiliki aktivitas dengan kategori K (kurang).

\section{b. Hasil Pembelajaran Siklus 1}

Kegiatan dalam pertemuan 2 (siklus 1) memuat fase memcoba, dan menyimpulkan sehingga selain observasi terhadap aktivitas siswa juga dilakukan penilian terhadap tugas kelompok, dan dilakukan uji kompetensi. Hasil pembelajaran pada siklus 1 dapat dipaparkan sebagai berikut.

1). Keaktivan siswa pada siklus 1 mencapai $88,89 \%$ dengan rincian: (1) nilai keaktifan $81,48 \%$; (2) nilai perhatian $81,48 \%$; dan (3) 
nilai tanggung jawab 88,89\%. Dari 9 siswa terdapat $6(66,67 \%)$ siswa memiliki aktivitas dengan kategori B (baik), 3 (33,33\%) siswa memiliki aktivitas dengan kategori C (cukup), dan tak seorangpun siswa yang memiliki aktivitas dengan kategori $\mathrm{K}$ (kurang). Namun demikian siswa masih merasa malu dan kurang berani mempresentasikan hasil kerja kelompoknya.

2). Hasil kerja kelompok pada siklus 1 sudah mengembirakan, memiliki nilai maksimum 100 , rata-rata 96,67 dan terendahnya 90. Dari 3 kelompok terdapat 2 kelompok yang nilainya 100, sedangkan 1 kelompok yang lainya nilainya sudah mencapai 90. Untuk kelompok yang belum mendapatkan niali 100 akan mendapatkan perhatian yang lebih.

3). Hasil belajar siswa pada siklus 1 juga sangat baik, hal ini ditunjukkan pada hasil uji kompetensi dengan nilai maksimum 100, nilai rata-rata 89,44 dan nilai terendahnya 70 . Dari 9 siswa terdapat $8(93,33 \%)$ siswa yang nilainya sama atau melebihi KKM (76) dan ada 1 $(6,67 \%)$ siswa yang nilainya masih dibawah KKM (76).

\section{c. Hasil Pembelajaran siklus 2}

Kegiatan dalam siklus 2 pada umumnya sama dengan kegiatan pada pertemuan kedua. Perbedaanya hanya pada sub pokok bahasannya saja. Sub pokok bahasan pada siklus 1 tentang menentukan invers fungsi linear, kuadrat, dan rasional, sedangkan sub pokok bahasan pada siklus 2 adalah menentukan invers fungsi eksponen dan logaritma. Hasil pembelajaran pada pertemuan ketiga dapat dipaparkan sebagai berikut.

1). Keaktivan siswa pada siklus 2 lebih meningkat dibandingkan pada pertemuan pertama dan kedua. Pada pertemuan ketiga nilai keaktivan siswa mencapai 94,81\% dengan rincian: (1) nilai keaktifan 88,89\%; (2) nilai perhatian 100\%; dan (3) nilai tanggung jawab 100\%. Seluruh siswa memiliki aktivitas dengan kategori B (baik).

2). Hasil kerja kelompok pada siklus 2 sangat mengembirakan (sudah optimal), semua kelompok telah mencapai niali 100 .

3). Hasil belajar pada siklus 2 juga siswa juga sangat luar biasa, nilai maksimum 100, nilai rata-rata 97,50 dan nilai terendahnya 90 . Semua siswa tuntas (nilainya melebihi $\mathrm{KKM}=76$ ), ketuntasan belajar klasikalnya adalah $100 \%$.

\section{GAMBARAN HASIL ANALISIS DATA}

Gambaran data proses dan hasil pembelajaran Pendekatan Ilmiah (Scientific Approach) dengan Prosedur Undo pada kompetensi dasar menentukan invers suatu fungsi di kelas XI-IPA-7 (Akselerasi) semester genap tahun pelajaran 2015-2016 SMAN 2 Kuningan yang dilakukan 
dalam 2 siklus dapat digambarkan sebagai berikut.

\section{Analisis Hasil Aktivitas Siswa}

Hasil aktivitas siswa dalam 2 siklus mengalami peningkatan yang cukup memuaskan. Peningkatan tersebut dapat digambarkan dengan diagram sebagai berikut.

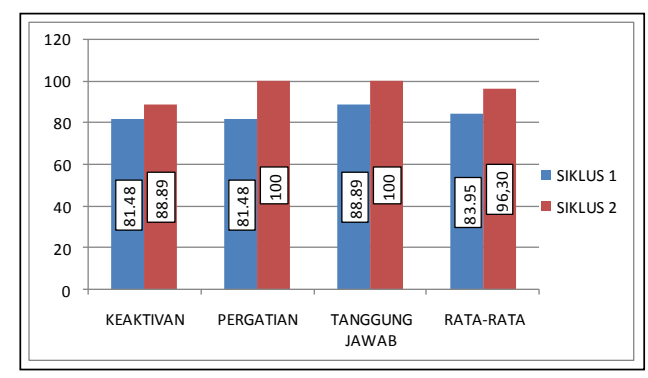

Gambar 3. Diagram Hasil Aktivitas Siswa dalam 2 Siklus

\section{Analisis Hasil Kerja Kelompok}

Hasil kerja kelompok siswa dalam 2 siklus mengalami peningkatan yang cukup memuaskan. Peningkatan tersebut dapat dideskripsikan pada diagram sebagai berikut.

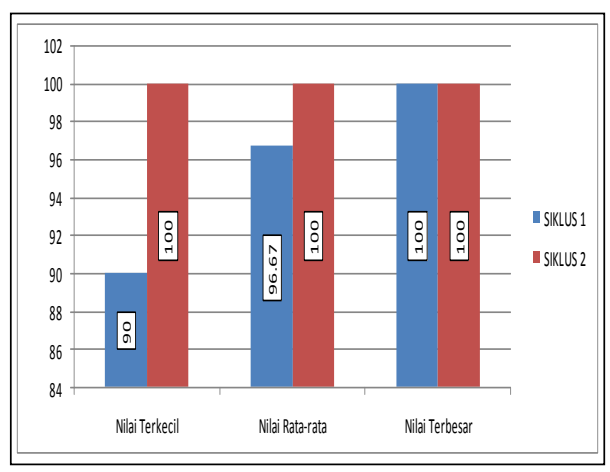

Gambar 5. Histogram Hasil Kerja Kelompok dalam 2 Siklus

\section{Analisis Hasil Tes Akhir}

Hasil uji kompetensi siswa juga mengalami peningkatan yang cukup memuaskan. Peningkatan tersebut dapat dideskripsikan pada diagram sebagai berikut.

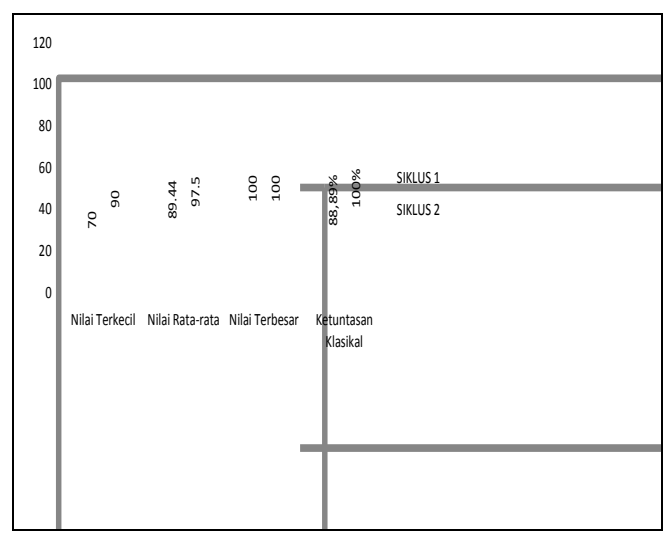

Gambar 5. Data Hasil Tes Awal dan Tes Akhir dalam 2 Siklus

Berdasarkan pembahasan hasil penelitian tindakan kelas yang peniliti lakukan selama 2 siklus membuktikan bahwa penerapan pembelajaran Pendekatan Ilmiah (Scientific Approach) dengan Prosedur Undo dapat meningkatkan hasil belajar siswa kelas XI-IPA-7 (Akselerasi) semester Ganjil tahun pelajaran 20142015 SMAN 2 Kuningan pada kompetensi dasar menentukan invers suatu fungsi. Berikut ini dideskripsikan beberapa alasannya sebagai berikut.

Pertama, terdapat peningkatan hasil uji kompetensi dalam setiap siklusnya. Rata-rata hasil uji kompetensi pada siklus I adalah 88,44 meningkat pada siklus II menjadi 97,50 . 
Kedua, terdapat peningkatan hasil kerja kelompok dalam setiap siklusnya. Rata-rata hasil kerja kelompok pada siklus I adalah 96,67 meningkat pada siklus II menjadi 100.

Ketiga, terdapat peningkatan hasil aktivitas siswa dalam setiap siklusnya. Aktifitas siswa pada siklus I 83,95 meningkat pada siklus II menjadi 96,30 .

\section{SIMPULAN}

\begin{tabular}{llr}
\multicolumn{2}{c}{ Berdasarkan } & hasil \\
pembelajaran & dalam dua & siklus \\
membuktikan & bahwa penerapan \\
pembelajaran & Pendekatan & Ilmiah
\end{tabular} (Scientific Approach) dengan Prosedur Undo dapat meningkatkan hasil $\begin{array}{lll}\text { belajar siswa kelas XI-IPA-7 } & \end{array}$ (Akselerasi) semester genap tahun pelajaran 2015-2016 SMAN 2 Kuningan pada kompetensi dasar menentukan invers suatu fungsi. Berikut ini dideskripsikan beberapa alasannya sebagai berikut.

1. Hasil aktivitas siswa sangat baik. Aktifitas siswa pada siklus 2 adalah 83,95 meningkat pada siklus 2 menjadi 96,30.

2. Hasil kerja kelompok sangat optimal. Rata-rata hasil kerja kelompok pada siklus 1 adalah 96,67 meningkat pada siklus 2 menjadi 100 .

3. Hasil uji kompetensi sangat tinggi. Rata-rata hasil uji kompetensi pada siklus 1 adalah 88,44 meningkat pada siklus 2 menjadi 97,50 .

\section{SARAN}

Berdasarkan hasil pembahasan pembelajaran Pendekatan Ilmiah (Scientific Approach) dengan Prosedur Undo) dalam meningkatkan hasil belajar siswa kelas XI-IPA-1 semester Genap SMAN 2 Kuningan tahun pelajaran 2015-2016 pada kompetensi dasar menentukan invers suatu fungsi, dapat disampaikan beberapa saran: (1) Kepada para guru SMA kelas XI, disarankan memilih Pendekatan Ilmiah (Scientific Approach) dengan Prosedur Undo dalam rangka meningkatkan hasil belajar pada kompetensi dasar menentukan invers suatu fungsi dan meningkatkan aktivitas belajar pada siswa, (2) Kepada pihak sekolah disarankan untuk memberikan motivasi kepada para guru agar senantiasa menerapkan Pendekatan Ilmiah (Scientific Approach), dan (3) Kepada peneliti lain disarankan agar mencoba melakukan penelitian tindakan kelas yang menerapkan Pendekatan Ilmiah (Scientific Approach) untuk pokok bahasan yang lainnya.

\section{DAFTAR PUSTAKA}

Kemendiknas. (2013) Modul Pelatihan Implementasi Kurikulum 2013. Jakarta: Kemendiknas.

Leithold Louis. (1992) Kalkulus dan Geometri Analitis Jilid I edisi kelima(Terjemahan). Erlangga, Jakarta.

Sartono Wirodikromo, 2012. Matematika SMA Kelas XI. Erlangga, Jakarta. 


Sudarmoyo. (2007) Multimedia
Pembelajaran Matematika
pada Kompetensi Dasar
Menentukan Invers Fungsi,
Makalah disajikan dalam
lomba media pembelajaran
yang diselenggarakan oleh
LPMP Jawa Barat.

Sukayati. (2008) Pembelajaran Tindakan Kelas. Yogyakarta: PPPG Matematika.

Suwah Sembiring. (2012) Matematika

XI IPA, Bandung:

Yramawidya. 